\title{
Effects of Management Practices on Soil Nutrient Levels in Sabke Catchment Area, Nigeria
}

\author{
S.A. Mashi, A. Yaro and A.I. Inkani
}

Received: 3001 2015 / Accepted: 01052015 / Published online: 15022016

(C) 2015 Faculty of Geography UGM and The Indonesian Geographers Association

\begin{abstract}
In Nigeria's drylands, profitable crop production requires adequate soil fertility management. This study examines the effects of farmer-managed practices on soil fertility in Sabke catchment of the drylands. Seven sites under permanent cropland, fallow land, grassland, shrubland, orchard land, intercropping land and woodland distributed on four transects were selected across the catchment. At every site, five replicate soil samples were collected from $0-15 \mathrm{~cm}$ (topsoil) and 20-30 cm (subsoil) and analysed for C, N, P, Ca, Mg, K and Na. Higher topsoil values of most of the properties were observed under cropland and intercropping sites. The two cultivated plots receive annual applications of organic manure in addition to chemical fertilizer and crops residue retention while the other plots are not. Thus, improvement in soil organic matter and nutrients would be expected in soils of the area with high rate of application of manure and chemical fertilizer, and retention of crop residues.
\end{abstract}

Keywords: Soil organic matter, Nutrients, Land, Management practices, Topsoil, Subsoil, Sabke Catchment

\begin{abstract}
Abstrak Di lahan kering Nigeria, produksi tanaman menguntungkan mengharuskan manajemen kesuburan tanah yang memadai. Penelitian ini meneliti efek dari praktek petani yang dikelola pada kesuburan tanah di Sabke tangkapan dari lahan kering. Tujuh lokasi di bawah lahan pertanian permanen, tanah kosong, padang rumput, semak, tanah kebun, lahan tumpangsari dan hutan didistribusikan pada empat transek dipilih di daerah tangkapan. Pada setiap situs, lima sampel tanah mereplikasi dikumpulkan dari 0-15cm (tanah lapisan atas) dan 20-30cm (subsoil) dan dianalisis untuk $C, N, P, C a$, $\mathrm{Mg}$, $\mathrm{K}$ dan $\mathrm{Na}$. Nilai tanah lapisan atas yang lebih tinggi dari sebagian sifat diamati di bawah lahan pertanian dan tumpang situs. Kedua plot dibudidayakan menerima aplikasi tahunan pupuk organik selain pupuk kimia dan retensi tanaman residu sementara plot lain tidak. Dengan demikian, peningkatan bahan organik tanah dan nutrisi diharapkan dapat terjadi pada tanah dari daerah dengan aplikasi pupuk kandang dan pupuk kimia tingkat tinggi, dan retensi sisa tanaman.
\end{abstract}

Kata kunci: Bahan organik tanah, Nutrisi, Tanah, Praktik manajemen, Bunga tanah, Lapisan tanah sebelah bawah, Sabke Catchment

\section{Introduction}

One issue that is of much scientific interest to resource managers in drylands of Africa is the ways in which land management practices are influencing soil nutrient levels. This is particularly so because nutrient levels is one major factor that determine human use of soil and hence wide range of economic activities. For long, soil productivity has been well noted as having significant influence on distribution of human population in many areas over the earth's surface. As population pressure on soil becomes high, there is the fear that soil degradation can occur. However, the

S.A. Mashi

Department of Geography and Environmental Management, University of Abuja, PMB 117, Abuja, Nigeria

Email: saniamashi@gmail.com

A. Yaro and A.I. Inkani

Department of Geography, Umaru Musa Yar'adua University of Abuja, PMB 2218, Katsina, Nigeria extent of such degradation tends to depend on the ways in which human beings manage the land.

In drylands of Africa, increasing population pressures has led to gradual disappearance of lands under long standing bush fallow and protected forest cover. While long standing forests are now disappearing, cultivation is being extended onto hitherto protected forest and grazing reserves, as well as marginal lands that ordinarily ought not to have been put into crops production (Reij et al. 1996; Mortimore and Adams 1999; Okike et al. 2001). Even under humid ecosystems, studies have shown that increasing invasion of forested and marginal areas by cultivation practices as a result of increasing population pressure have been causing land degradation, with organic matter and nutrients declining being the major effects (Oldeman, et al., 1990; Mahtab and Karim, 1992; Niemeijer and Mazzucato, 2002; Wang et al., 2003).

For long, the UN has noted such declining 
occurring in arid, semiarid and dry sub-humid areas that results from various factors, including climatic variations and human activities as a major threat to attainment of food security in especially sub-Saharan Africa (UNCED, 1992).

Synthesising the findings of studies conducted in several dryland areas of Africa, Tiffen and Mortimore (2002) noted that as family farms become smaller under conditions of population growth, while some people out-migrate others remain behind to raise the value of output (crops or livestock) per hectare. Long-term data for selected countries and areas on environmental recovery resulting from deliberate human efforts to reverse land degradation in drylands of sub-Saharan Africa provide some evidence of positive trends, with case studies showing that adaptive strategies of small farmers to counter land degradation include techniques to improve fertility, conserve water, manage trees, increase livestock, and take advantage of changing markets (Tiffen, et al. 1994; Tiffen and Mortimore, 2002). However, such successes even if they are achieved are often challenged by inconsistency and unreliability of government policies (such as on provision of inputs and market opportunities), relatively high poverty levels and highly variable nature of rainfall in drylands. Thus, though the farmers in Africa's drylands might be doing their best to adapt and improve the fertility of their soils, changing climatic, economic and political scenarios can provide some enormous challenges that can erode their efforts.

Due to lack of systematic research investigations for many locations in Africa's drylands, there is inadequate research information on the efficacy of farmer management of soil fertility. This study seeks to advance an understanding in this regard using Sabke Catchment area of northern Nigeria (located in drylands of West Africa) as a case study. Cambardella et al. (1994) and Wang et al. (2003) have noted that a better understanding of the characteristics of soil nutrients at the field and catchment scale is important for refining agricultural management practices and for improving sustainable land use.

The objectives of this study was to assess the effects of land management practices on soil nutrients levels (Carbon, Nitrogen, Phosphorous and Exchangeable Cations) in Sabke area of Nigeria's semi-arid region, with a view to understanding the extent to which farmer management of the soils influence their fertility levels in the area.

\section{The Methods}

The Sabke Catchment area (12'59.831N and 8 '5.274E) is situated in northern part of Katsina state, one of the seven states in the northernmost region of Nigeria that constitutes the semi-arid region of the country.

The area has an altitude between 360 and $450 \mathrm{~m}$ within an area of about $19.7 \mathrm{~km}^{2}$, lying within an extensive plain locally known as the 'High Plains of Hausaland. The area has a semiarid climate with an average annual temperature of between $18^{\circ} \mathrm{C}$ and up to $30^{\circ} \mathrm{C}$ (December to March) and $30^{\circ} \mathrm{C}$ to $45^{\circ} \mathrm{C}$ (April to November) every year. The average annual precipitation is $562 \mathrm{~mm}$ with $70 \%$ percent of the rainfall falling between July and September. Water and wind erosion respectively are very high during the rainy and dry seasons. The soils are mainly wind-deposited loess parent material, and were classified as typic Entisols. The soils are predominantly loess and have a texture of silt ranging from $64 \%$ to $73 \%$ and clay varying from $9 \%$ to $18 \%$.

The major land management practices in the area comprised permanent cultivation cropland, fallow land, grassland, shrub land, orchard land, intercropping cultivation land and woodland in the study area. Crops were mainly sweet potatoes, millet (Panicum miliaceum), and beans (Phaseolus valgaris). The forest, artificial woods, was dominated by Neem (Azadricha indica) and Eucalyptus (Eucalyptuscamaldulensis) trees. The grassland was mainly covered by annuals such as Gamba (Andropogon gayanus) and Schofield Stylo (Stylosanthesisguianensis). Aduwa (Balenitesaegyptica) and Mango (Magniferaoliveri) existed on the shrubland and orchard, respectively.

The fallow landsare usually allowed to rest for two to three years after five to ten years of continuous cultivation depending upon farmers' choice and land's productivity. There were crops and Mango trees on the intercropping land. Fertilizer management for crop included a pre-planting application of animal manure at quantities that depend on availability (which vary from time to another) and chemical fertilizer at rates prescribed by local extension agents $(60 \mathrm{Kg} / \mathrm{N}$ per hectare, $60 \mathrm{Kg} \mathrm{P}_{2} \mathrm{O}_{5}$ per hectare and $30 \mathrm{Kg} \mathrm{K} \mathrm{K}_{2} \mathrm{O}$ per hectare).

Fourty-nine sampling sites distributed at 20-m intervals on four transects were selected across the Sabke catchment (Figure 1), with seven sites each for each of the seven major landuse types identified in the area (permanent cultivation cropland, fallow land, grassland, shrub land, orchard land, intercropping cultivation land and woodland). The four transects were selected across the study area in a way as to ensure that they cut across the six categories of landscape positions identified in the area (upper interfluve, lower interfluve, shoulder, upper linear, lower linear and foot slope). The upper slope position, relative to upper interfluve and lower interfluve, is the uppermost portion of the hillslope. It receives little or no overland flow but may contribute runoff to the downslope position. The middle position consisting of shoulder, upper linear and lower linear receives overland flow from the upper slope and contributes runoff to the foot slope. The foot slope represents the base of the hill. Water and sediment running off the foot slope may enter a waterway or other water conveyance systems. 


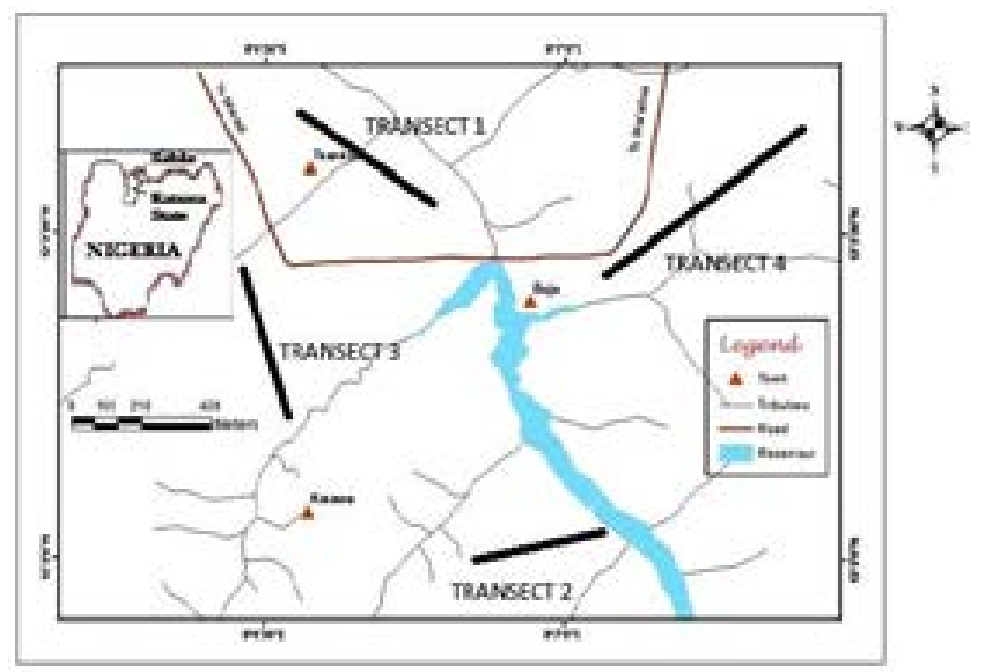

Figure 1. Transects location in Sabke catchment area

In April 2012, five replicate soil samples were collected from every site at $0-15 \mathrm{~cm}$ (topsoil) and 20 $30 \mathrm{~cm}$ (subsoil) using soil auger. The collected samples were adequately labeled after the collecting site, landuse and depth and then transported to the laboratory for analysis. While in the laboratory, the samples were airdried and sieved to remove gravel fractions after which $10 \mathrm{~g}$ sub-samples were taken for detailed analyses. Standard soil procedures employed in the analyses: Total nitrogen (TN) was determined by the semi-micro Kjeldahl method; and Total Phosphorous (TP) was determined colorimetrically after wet digestion with $\mathrm{H}_{2} \mathrm{SO}_{4}+\mathrm{HClO}_{4}$ (Parkinson and Allen, 1975); Avaialble Nitrogen (AN) was determined by using a microdiffusion technique after alkaline hydrolysis (Conway 1989)and Available Phosphorous (AP) was determined by Olsen method (Emteryd, 1989). Soil organic carbon was determined by oil bath- $\mathrm{K}_{2} \mathrm{CrO}_{7}$ titration method (Nelson and Sommers 1975) and the value obtained was multiplied by 1.725 to derive Soil Organic Matter (SOM) value. The Exchangeable Cations ( $\mathrm{Ca}, \mathrm{Mg}, \mathrm{K}$ and $\mathrm{Na}$ ) in the soil samples were extracted using Ammonium Acetate extraction procedure and from the extracts obtained proportions of $\mathrm{Ca}$ and $\mathrm{Mg}$ were determined using atomic absorption spectrophotometry and those of $\mathrm{K}$ and $\mathrm{Na}$ using flame emission photometry.

Descriptive statistics (mean and standard deviation) were computed for every soil property for each landuse ANOVA was performed to assess the effects of land uses on SOM and soil nutrients. The relationships between SOM and nutrients were determined by correlation analysis, with the former considered as the independent and the latter the dependent variable. All the statistical analyses were conducted using SPSS program (SPSS Inc., 1993).

\section{Result and Discussion}

Table 1 presents the mean and standard deviation values of each of the soil nutrients determined in the soil samples collected from the lands under different farmer management practices in the study area, for both the topsoil and subsoil. The table also gives the ANOVA F-values assessing the significance of the differences in mean values of every nutrient element for the seven management practices considered.

SOM is considered as the best surrogate for soil quality because of the roles in plays in promoting good soil functions the development and maintenance of soil structure, water holding capacity, nutrient and organic carbon storage, and the maintenance of biological activity (Dumanski and Pieri 2000; Murage et al., 2000).

Mean values of Organic Carbon (OC) and SOM in the $0-15 \mathrm{~cm}$ soil layer follow this trend: Fallow land > Intercropping land $>$ Cropland $>$ Orchard $>$ Woodland $>$ Shrubland $>$ Grassland. In the $20-30 \mathrm{~cm}$ soil layer, the trend was: $>$ Intercropping land $>$ Orchard $>$ Shrubland $>$ Fallow land $>$ Cropland $>$ Grassland $>$ woodland. The values are generally higher at the upper than the lower layer reflecting presumably the higher organic activities of the former layer. The differences in mean values of the two properties are significant at the upper layer only which suggests that the effects of the landuse types on organic carbon and matter levels is restricted mainly to the top layer. This is partly expected since organic activities that promote organic matter build-up tend to predominate in the upper layer.

Three things could be observed here. First, in the upper layer, fallowing has helped to raise the organic matter level of the soils more than any other landuse. This is partly expected since the fallow plot has been left to lie for some years after period of cultivation and during the cultivation cycle it was receiving some applications of organic manure. This suggests that improved fallow system with organic manure amendment can greatly help in addressing organic matter deficiency of dry savanna soils.

Second, cultivated plots receiving organic manure amendment (intercropping and cropland) maintain the second and third best organic matter levels in the topsoil and this may be a reflection of annual dressing 
Table 1. Mean, Standard Deviation (S.D.) and ANOVA F-Values of Soil Organic Matter and Soil Nutrients Measured in Different Land Management Practices

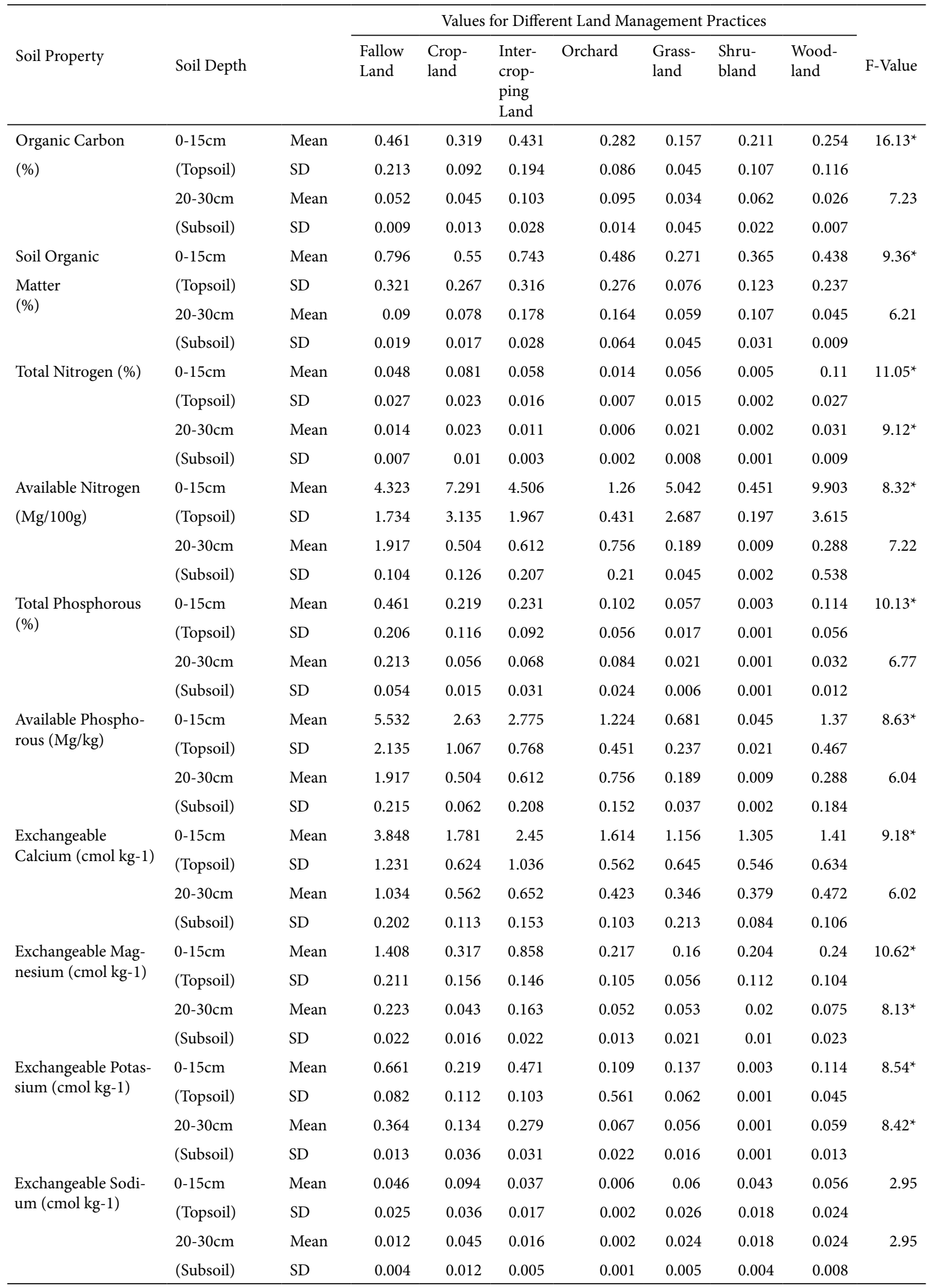

Note: The Asterik denote mean values that are statistically significant at 0.005 probability level 
of the plots with organic manure in the area. As the manure is added to the upper layer and not thoroughly mixed in the soil, its significant influence was found to be restricted to that layer only. The cultivated plots are receiving more management practices including more manure addition, and regular weeding plus incorporation of the debris into the soil to decay/ decompose into organic matter.

Third, in the upper layer, plots with woody tree species (Orchard, Woodland and Shrubland) have comparatively lower contributory effects to organic matter accumulation than the cultivated plots in the area, but in the lower layer opposite trend was observed. This suggests that the contribution of standing vegetation (trees and shrubs) to organic matter buildup in the study area is restricted mainly to the subsoil, reflecting presumably additions through roots' decay. In the upper layer, the falling litter is easily removed either by erosion or livestock browsing and this gives little room for the litter to decay and contribute to organic matter build-up.

Some research workers have observed that SOM level would decrease after land use shifts from the woodland and grassland to cultivated land (Davidson and Ackerman 1993; Lepsch et al. 1994; Islam and Weil 2000). In the study area, a slightly different observation was made as the cultivated plots were found to have more SOM levels than woodland, fallow and grass fallow plots. The study area is hot and dry, and has sandy soils that are poorly vegetated and hence, the contributions of standing vegetation (trees, shrubs and grasses) to organic matter build-up are expected to be low. Where organic manure addition is added to such soils, it can help to raise SOM level beyond what the standing vegetation can typically contribute.

The SOM levels of soils of the area are generally low and this could also be attributed to the low C input due to low vegetation cover, high litter oxidation (due to solar heating), and high incidence of wind and water erosion. In addition, crop residues like millet and bean stalks are used to feed animals or used as fuel for cooking.

Several research workers have attributed low organic matter level of tropical soils of dry areas to the return of little or no agricultural residue (Lal 1986;Bouwman 1990; Post and Mann 1990, high rate of transformation and translocation of organic materials in tropical soils (Ojanuga 1971), continuous cropping, and annual bush burning (Roze 1989; Issaka et al. 1997). Ojanuga (1971) also considers low polymerisation rate of humic compounds into stable chelates, in addition to rapid rate of illuviation as significant contributors to low organic matter in tropical soils.

In the case of Total and Available Nitrogen, variations in the mean values follow this trend: Woodland $>$ Cropland $>$ Intercropping land $>$ Grassland $>$ Fallow land $>$ Orchard $>$ Shrubland. In general, the woody species and crops cultivation practices involving addition of organic manure have comparatively higher levels of the property than the other plots in the area. This is most likely a reflection of the contributory effects of organic manure application to $\mathrm{N}$ accumulation in soils. Also, under the cultivated plots, continuous application of organic manure help to improve porosity, microbial activity and higher moisture levels which can in turn help in raising soil $\mathrm{N}$ level. Islam and Weil (2000) have shown that poorer macroaggregate and lower organic activities typically lower don $\mathrm{N}$ levels in soils.

Like organic matter, $\mathrm{N}$ contents are significantly different between the landuse types at the topsoil. The similarity in patter between organic matter and nitrogen is expected given that the latter is the major source of the former in soils. In tropical soils of low activity clays (such as the type in the study area), manure application is considered as the main method of enhancing soil $\mathrm{N}$ levels (Sanchez 1994).

In general, there seem to be a similarity in pattern between SOM and $\mathrm{N}$ is soils of the study area. This is not unexpected as SOM is known to be influencing $\mathrm{N}$ retention and supply (Brubaker et al. 1993).

The $\mathrm{N}$ levels of soils of the area can be described as low and this is not surprising given that sandy soils of dry ecosystems are generally low in organic matter and most nutrient elements including N (Jones and Wild 1975; Sanchez, 1994).

Variations in Mean values of Total and Available Phosphorous follow this trend: Fallow land $>$, Intercropping land $>$ Cropland $>$ Woodland $>$ Orchard $>$ Grassland $>$ Shrubland. The property is significantly different between the landuse types only in the topsoil. In general, the cultivated plots (intercropping and cropland) maintain comparatively higher levels of the property than the other plots and this most likely reflect the applications of chemical fertilizer and organic manure in soil fertility maintenance over the two plots. While $\mathrm{P}$ is a major component of the NPK fertilizer being used, organic manure is known to store important amounts of $\mathrm{P}$ which is easily released when applied to soils.

Some research workers (Pacovsky 1986; Gnekow and Marschener 1989) have shown that most of P in soils is held very firmly in crystal lattices of largely insoluble forms, such as various $\mathrm{Ca}, \mathrm{Fe}$ and $\mathrm{AlPO}_{4}-\mathrm{s}$, and also is chemically bonded to the surface of clay minerals. Thus higher mycorrhizal roots of crops compared to standing vegetation (trees, shrubs and grasses) are expected to help in raising $\mathrm{P}$ levels of the cultivated plots.

Available phosphorous is low due to the nature of parent material and, to a limited extent, erosion, leaching, and low organic matter content apparent in the study area. The values are similar to the values earlier reported by Fagbami and Akamigbo (1986) for the zone. However, no relationship appears to exist between organic matter content and available $\mathrm{P}$ in soils of the area. $\mathrm{N}$ and $\mathrm{P}$ are the most limiting nutrients while $\mathrm{K}$ and micronutrient deficiencies are not prevalent in the 
Savannah (Lombin 1987). In many natural ecosystems, $\mathrm{P}$ availability limits overall ecosystem productivity (Tiessen 1993).

It could be seen from Table 1 that with the exception of $\mathrm{Na}$, all the base elements are significantly different between the land management practices with the values of $\mathrm{Ca}, \mathrm{Mg}$ and $\mathrm{K}$ are comparatively higher in the two cultivated plots than the other plots and this may be a reflection of the role of organic matter (which is higher in the two plots) in raising values of exchangeable cations. Miller and Donahue (1990) explained that in the tropics, the percentage of the total exchangeable cations due to organic matter varies from 51 for the A-horizon to 22 for the B-horizon which indicates the relevance of organic matter to the exchangeable cations and Effective CEC (Cation Exchange Capacity) in tropical areas. They further stated that the most fertile soil would have perhaps only $10 \%$ exchangeable hydrogen and $90 \%$ total exchangeable bases such as $\mathrm{Ca}^{2+}(75 \%), \mathrm{Mg}^{2+}(10 \%)$, and $\mathrm{K}^{+}(5 \%)$.

\section{Conclusion}

On the bases of the results obtained here, it could be concluded that the two cultivated plots (cropping land and intercropping land) in general maintain comparatively better soil quality level that the plots under the other land management practices in the study area. The two plots are receiving application of organic manure on annual basis in addition to chemical fertilizer while the other plots are not. This once again underscore the important role organic matter plays in maintaining soil fertility in tropical soils of low activity clays, such as the type found in Nigeria's semi-arid region where the study area is situated.

Tropical conditions encourage high rate of organic high rate of organic matter mineralization and hence where organic manure is not added to compensate for such loses, levels of SOM and other macronutrients (especially $\mathrm{N}, \mathrm{P}, \mathrm{K}, \mathrm{Ca}$ and $\mathrm{Mg}$ ) are expected to be low. As a way of ensuring agricultural sustainability in the study area, it is recommended here that increased and sustained use of organic manure is maintaining soil fertility should be promoted not only under cultivated conditions but even for soils under fallow or standing vegetation cover (woodlands and orchards).

The soils in the study area are generally low in organic matter content and this poses the danger of soil deterioration, low plant nutrient reserves, and low CEC especially under poor management. Thus, the tendency of laying too much emphasis on organic fertilizer applications in soil fertility maintenance should as much as possible be discourage in favour of more intensive use of organic manure. As Yu (1989) suggested, the amounts of SOM and total $\mathrm{N}$ in the solum should be stressed because of their significance in plant nutrition. The use of organic manures has long been recognised in maintenance of organic matter status, nutrient supply and in amelioration of soil physical properties
(Sanchez et al. 1989; Swift and Anderson 1991), especially in the tropics where socio-economic factors limit the use of inorganic fertilizers. More particularly, use of organic manure can ameliorates the effect on nutrient deficiency, detoxifies harmful soil constituents, increases moisture and nutrient retention, moderates temperature and enhances soil structural development. Miller and Donahue (1990) stated that crops on a field diminish or increase into exact proportion to the mineral substances conveyed to it in manures.

\section{References}

Bouwman, A.F. (1990). Exchange of greenhouse gases between terrestrial ecosystems and the atmosphere. In: Bouwman, A.F. (Ed.). Soils and the Greenhouse Effects. John Wiley and Sons, New York. pp 61-127.

Brubaker, S.C., Jones, A.J., Lewis, D.T. and Frank, K. (1993), Soil properties associated with landscape positions. Soil Science Society of America Journal, 57, 235-239

Cambardella, C.A., Moorman, T.B., Novak, J.M., Parkin, T.B., Karlen, D.L., Turco, R.F. and Konopka, A.E. (1994). Field-scale variability of soil properties in Central Iowa soils. Soil Science Society of America Journal, 58, 1501-1511.

Conway, A. (1978). Soil physical-chemical analysis. Institute of Soil Science, Nanjing. Technology Press, Shanghai, China, pp. 76-78.

Davidson, E.A. and Ackerman I.L. (1993). Changes in soil carbon inventories following cultivation of previously untilled soils. Biogeochemistry 20, 16193.

Dumanski, J. and Pieri, C. (2000). Land quality indicators: research plan. Agriculture, Ecosystems and Environment, 81, 93-102.

Emteryd, O. (1989). Chemical and physical analysis of inorganic nutrients in plant, soil, water and air. Swedish University of Agricultural Sciences, Uppsala, Sweden.

Fagbami, A. and Akamigbo, F.O.R. (1986). The soils of Benue State and their capabilities. 14th Annual Conference of soil Science Society of Nigeria, Makurdi, Nigeria.

Gnekow, M.A. and Marschner, H. (1989). Role of VAmycorrhiza in growth and mineral nutrition of apple (Malus pumila var. domestica) stock cuttings. Plant and Soil, 119, 285-293.

Islam, K.R. and Weil, R.R. (2000).Land use effects on soil quality in a tropical forest ecosystem of Bangladesh. Agriculture, Ecosystems and Environment, 79, 9-16.

Issaka, R.N., Ishida, F., Kubota, D. and Wakatsuki, T. (1997). Geographical distribution of selected soil fertility parameters of inland valleys in West Africa. Geoderma, 75 (1-2), 99-116.

Jones, M.J. and Wild, A. (1975): Soils of the West Africa Savanna. Commonwealth Agricultural Bureau, Harpenden, UK. 
Lal, R. (1986). Soil surface management in the tropics for intensive land use and high and sustained productivity. In: Steward, B.A. (Ed.). Advances in Soil Science (Vol. 5) New York, USA: SpringerVerlag. pp 16-29.

Lepsch, I.F., Menk, J.R.F. and Oliveira, J.B. (1994). Carbon storage and other properties of soils under agriculture and natural vegetation in Sao Paulo State, Brazil. Soil Use and Management, 10, 34-42.

Lombin, L.G. (1987). Soil and climatic constraints to crop production in the Nigerian Savannah region. 15th Annual Conference of Soil Science Society of Nigeria, Kaduna, Nigeria.

Mahtab, F.U. and Karim, Z. (1992). Population and agricultural land use: towards a sustainable food production system in Bangladesh. Ambio, 21, 5055.

Miller, R.W. and Donahue, R.L. (1990). Soils: An Introduction to Soil and Plant Growth. Prentice Hall, Englewood Cliffs, NJ (1990), 768 pp.

Mortimore, M., Adams, W.M. (1999). Working the Sahel: Environment and Society in Northern Nigeria. Routledge, London.

Murage, E.W., Karanja, N.K., Smithson, P.C. and Woomer, P.L. (2000). Diagnostic indicators of soil quality in productive and non-productive smallholders' fields of Kenya's Central Highlands. Agriculture, Ecosystems and Environment, 79, 1-8.

Nelson, D.W. and Sommers, L.E. (1975). A rapid and accurate method for estimating organic carbon in soil. Proceedings of the Indiana Academy of Science, 84, 456-462.

Niemeijer, D. and Mazzucato, V. (2002). Soil degradation in the West African Sahel: How serious is it? Environment 44(2), 20-31.

Ojanuga, A.G. (1971). A study of soils and soil genesis in the South Western Upland of Nigeria. PhD Thesis, University of Wisconsin, Madison, WI, USA.

Okike, I., Jabbar, M.A., Manyong, V., Smith, J.W., Alinwumi, J.A.and Ehui, S.K. (2001). Agricultural intensification and efficiency in the West African savannahs: Evidence from northern Nigeria. Socio Economics and Policy Research Working Paper 33. ILRI, Nairobi, Kenya.

Oldeman, L.R., Hakkeling, R.T.A. and Sombroek, W.G., 1990. World map of human-induced soil degradation. ISRIC, Wageningen, The Netherlands, UNEP, Nairobi.

Pacovsky, R.S. (1986). Micronutrient uptake and distribution in mycorrhizal or phosphorusfertilized soybean. Plant and Soil, 95, 379-388.

Parkinson, J.A. and Allen, S.E. (975). A wet oxidation procedure suitable for determination of nitrogen and mineral nutrients in biological material. Communications in Soil Science and Plant Analysis, 6, 1-11.

Post, W.M. and Mann, L.K. (1990). Changes in soil organic carbon and nitrogen as a result of cultivation. In: Bouwman, A.E. (Ed.), Soils and the Greenhouse Effect. John Wiley, Chichester, U.K. pp 97-103.

Reij, C., Scoones, I., and Toulmin, C. (1996). Sustaining the Soil: Indigenous Soil and Water Conservation in Africa. Earthscan, London.

Roze, F. (1989). Point country method for thin section interpretation. Rev. Ecol. Biol. Sol, 26 (2), 189-196.

Sanchez, P.A. (1994). Tropical soil fertility research: Towards the second paradigm. Transactions 15th International Congress of Soil Science, Acapulco I, 65-88.

Sanchez, P.A., Palm, C.A., Szott, L.T., Cuevas, E. and Lal, R. (1989). Organic input management in tropical agro ecosystems. In: Coleman, D.C., Oades, J.M. and Uehara, G. (Eds.), Dynamics of Soil organic matter in tropical ecosystems, NifTAL Project, Paia, HI, USA. Pp 67-79.

SPSS Inc., 1993. SPSS for windows base system user's guide release 6.0. Marija J. Norusis/SPSS Inc.

Swift, M.J. and Anderson, J.M. (1991). Biodiversity and ecosystem function in agricultural systems. In: Schultz, D. (Ed.). Biodiversity and ecosystem function, Springer Verlag, Berlin, Germany.

Tiessen, H. (1993). The study of phosphorous cycles in ecosystems. In: Anderson, J.M. and Ingram, J.S.I. (Eds.), Tropical soil biology and fertility: A handbook of methods. pp. 179-188.

Tiffen, M. and Mortimore, M. (2002). Questioning desertification in dryland sub-Saharan Africa. Natural Resources Forum 26, 218-233.

Tiffen, M., Mortimore, M., Gichuki, F., (1994). More people less erosion: environmental recovery in Kenya, Wiley, Chichester, England.

UNCED (1992). Earth Summit '92. The UN Conference on the Environment and Development, Rio

Wang, J., Fu, B., Qiu, Y. and Chen, L. (2003). Analysis on soil nutrient characteristics for sustainable land use in Danangou catchment of the Loess Plateau, China. Catena 54 (1-2), 17-29.

Yu, T.R. (1989). Use of organic matter/manure on upland acid soil in China. In Craswell, E., Pushparajah, E.T. (Eds.), Management of Acid Soils in the Humid Tropics of Asia, Australian Centre for International Agric. Research, Canberra, 44-51. 